\title{
ANALISIS PENCAPAIAN PEJABAT PENGELOLA INFORMASI DAN DOKUMENTASI PROVINSI DKI JAKARTA DALAM MERAIH PENGHARGAAN KETERBUKAAN INFORMASI PUBLIK TAHUN 2019
}

\author{
Khansa Henovanto ${ }^{1}$, Muhammad Mansur ${ }^{2}$, Siti Ghina ${ }^{3}$, Zahra Karyna Putri ${ }^{4}$ \\ ${ }^{1}$ Ilmu Administrasi Negara, Fakultas Ilmu Administrasi, Universitas Indonesia \\ Email: Khansa.henovanto@gmail.com \\ 2 Ilmu Administrasi Negara, Fakultas Ilmu Administrasi, Universitas Indonesia \\ Email: Mindmansur@gmail.com \\ 3 Ilmu Administrasi Negara, Fakultas Ilmu Administrasi, Universitas Indonesia \\ Email: Sitighina11@gmail.com \\ ${ }^{4}$ Ilmu Administrasi Negara, Fakultas Ilmu Administrasi, Universitas Indonesia \\ Email:ZZahrakaryna@gmail.com
}

\begin{abstract}
Abstrak
Pemerintahan yang baik adalah pemerintahan yang transparan dan dapat dipertanggung jawabkan. Hal ini senada dengan Undang-undang No. 14 Tahun 2008 tentang Keterbukaan Informasi Publik. Undang-undang ini menjadi salah satu hal yang perlu ditunaikan oleh tiap pemerintahan, tak terkecuali Pemerintah Provinsi DKI Jakarta. Pada tahun 2019, Komisi Informasi memberikan penghargaan Keterbukaan Informasi Publik bagi Pemerintah Provinsi DKI Jakarta di mana pemerintahan ini merupakan salah satu pemerintahan provinsi dengan permohonan informasi paling banyak dibanding provinsi lain. Berdasarkan hal tersebut, penelitian ini bertujuan untuk melihat dan menganalisis upaya apa saja yang telah dilaksanakan oleh Pemerintah Provinsi DKI Jakarta sehingga mampu mendapatkan penghargaan tersebut. Hasil analisis ini berhasil menemukan bahwa walaupun DKI Jakarta telah berhasil meraih penghargaan ini, tetap ada hal yang perlu menjadi evaluasi, sehingga analisis ini juga mencari permasalahan yang bisa menjadi bahan masukan baik bagi pemerintahan provinsi DKI Jakarta sendiri maupun pemerintahan provinsi lainnya agar terus menerapkan dan mendukung keterbukaan informasi publik.
\end{abstract}

Kata Kunci: Informasi, keterbukaan, penghargaan, dan publik

\begin{abstract}
A good government is one who applied transparency and accountability in their administration. This is similar to Indonesian law no. 14 of 2008 about Public Information Openness. This law has become an obligation for every government organization, including provincial government of DKI Jakarta. In 2019, DKI Jakarta has received an award from Information Commission by being one of the most government organizations that applied Public Information Openness. Moreover, DKI Jakarta has experienced being the most requested of any public informations. This research intends to find out what has provincial government of DKI Jakarta done until they reach the award. The result of this analysis is even
\end{abstract}


though DKI Jakarta has reach its succeed, there is few things that needs to be considered, so that it can be evaluated by DKI Jakarta itself or any other provincial government, along with the goals that all of the governments will always apply and support Public Information Openness.

Keywords: Appreciation, information, openness, public

\section{A. PENDAHULUAN}

Berdasarkan Undang-Undang Nomor 14 Tahun 2008 tentang Keterbukaan Informasi Publik (KIP), KIP memiliki tujuan untuk membuka akses informasi kepada publik, namun KIP terlebih dahulu mengatur klasifikasi informasi, sehingga memberikan kepastian dalam jenis informasi yang dapat diakses maupun yang tidak dapat diakses oleh publik. Secara teoritis, UU KIP menawarkan solusi bagi jurnalis, peneliti, dan masyarakat yang mengalami kendala ketika mengakses dokumen badan-badan publik. Melalui UU KIP, upaya untuk menyediakan ruang untuk mencapai Keterbukaan Informasi Publik mengalami peningkatan, sebagaimana pemerintah melalui badan publik tingkat pusat dan daerah mengembangkan dan menyelenggarakan sistem informasi dan dokumentasi yang dapat diakses oleh publik, sebagai bentuk penyelenggaraan hak akses informasi.

Perkembangan dari pengesahan UU KIP juga melahirkan nomenklatur baru dalam badan publik tingkat pusat dan daerah yaitu Pejabat Pengelola Informasi dan Dokumentasi (PPID). PPID sebagaimana disebut dalam UU KIP, merupakan pejabat yang bertanggung jawab di bidang penyimpanan, pendokumentasian, penyediaan, dan pelayanan informasi di badan publik. PPID memiliki peran strategis dalam menyampaikan informasi yang dibutuhkan oleh masyarakat, informasi yang dimaksud dapat berupa atau berkaitan dengan kinerja pemerintahan atau kemampuan pengelolaan keuangan daerah. Berbagai tindakan yang dilakukan oleh PPID dilakukan demi mewujudkan aspek tata kelola pemerintahan yang baik (good governance) dalam transparansi penyediaan informasi yang dapat diakses berbagai pihak. Selain melahirkan PPID, UU KIP juga melahirkan badan publik baru, yaitu Komisi Informasi (KI). Komisi Informasi merupakan lembaga mandiri yang berfungsi menjalankan UU KIP dan peraturan pelaksanaannya, serta menetapkan petunjuk teknis akan standar layanan informasi publik melalui mediasi atau adjudikasi nonlitigasi. Sehingga, KI memiliki peran dalam penyelesaian konflik apabila terjadi sengketa informasi publik, atau konflik 
antara badan publik dengan pengguna informasi publik tentang hak memperoleh serta menggunakan informasi publik.

Hasil implementasi dari UU KIP dalam Pemerintah Provinsi DKI Jakarta memiliki rekam jejak yang baik, implementasi berupa pengesahan Peraturan Gubernur Provinsi Daerah Khusus Ibukota Jakarta Nomor 175 Tahun 2016 tentang Layanan Informasi Publik, serta memperoleh penghargaan dari Komisi Informasi untuk kategori "Badan Publik Pemerintah Provinsi Kualifikasi Informatif" pada bulan November 2019. Dalam pelaksanaan penyediaan informasi publik, Pemprov DKI Jakarta melalui Pergub No. 175 Tahun 2016, menciptakan badan publik, yaitu PPID tingkat Provinsi untuk melakukan koordinasi penyimpanan, pendokumentasian, penyediaan layanan serta pengumuman seluruh informasi publik di Perangkat Daerah yang dapat diakses oleh publik sesuai dengan ketentuan peraturan perundang-undangan. Informasi publik dikumpulkan dengan cara pendataan informasi publik yang ada pada Perangkat Daerah untuk dilakukan pembuatan dan pemutakhiran daftar informasi publik dengan minimal 1 (satu) kali dalam 1 (satu) bulan.

Proses untuk memperoleh penghargaan "Badan Publik Pemerintah Provinsi Kualifikasi Informatif” oleh Komisi Informasi kepada PPID Provinsi DKI Jakarta dilakukan melalui berbagai kegiatan, tugas, serta program. Sebagaimana indikator penghargaan tersebut adalah kewajiban sesuai UU KIP yaitu memberikan akses informasi publik dalam berbagai aspek secara transparan khususnya tentang hasil kinerja Pemprov DKI Jakarta, maka berbagai tugas PPID Provinsi DKI Jakarta sebagaimana telah diatur dalam Pergub No.175 Tahun 2016 yaitu melakukan penyimpanan, dokumentasi, serta penyediaan pelayanan informasi kepada publik, lalu inventarisasi dan uji konsekuensi atas informasi yang dikecualikan, serta pemutakhiran informasi dan dokumentasi. Selanjutnya, melakukan koordinasi serta evaluasi dalam pengumpulan informasi dan kinerja dari PPID pada Perangkat Daerah, lalu konsultasi kepada Kementerian Komunikasi dan Informatika dan Komisi Informasi serta lembaga yang berhubungan dengan keterbukaan informasi.

Tindakan Pemerintah Provinsi DKI Jakarta untuk menyelenggarakan pelayanan terhadap akses informasi publik selain dengan menciptakan PPID tingkat Provinsi, juga menciptakan PPID untuk masing-masing Satuan Kerja Perangkat Daerah (SKPD). Upaya untuk menyelenggarakan keterbukaan informasi publik di DKI Jakarta menjadi lebih sinkron 
dengan PPID tingkat Provinsi dan SKPD, sebab melalui penyediaan informasi publik yang dikelola bersama, maka diharapkan data yang akan tersedia menjadi lebih akurat.

Akan tetapi, selain melakukan upaya untuk menyediakan data dan informasi publik yang diperbolehkan untuk digunakan berbagai pihak, serta hasil kinerja pemerintah daerah, Pemerintah Provinsi DKI Jakarta juga melakukan penyediaan data dalam pengelolaan keuangan daerah, seperti e-budgeting. Kegiatan e-budgeting adalah kegiatan untuk mengisi data Rancangan Anggaran Pendapatan, dan Belanja Daerah (RAPBD) tahun berikut dari setiap tahun anggaran. Melalui agenda e-budgeting, proses penyusunan RAPBD tahun anggaran selanjutnya dapat dibahas sebelum menjadi kesepakatan bersama. Sebagai bentuk akses penyediaan data terhadap informasi publik berupa pengelolaan keuangan daerah, Pemprov DKI Jakata melampirkan rancangan anggaran pada laman https://apbd.jakarta.go.id/. Namun, setelah melakukan penyediaan data, terdapat indikasi belum ada perencanaan anggaran yang baik. Sehingga, menjadi permasalahan apabila muncul data berupa anggaran belanja dengan nominal pembelian yang tidak wajar.

\section{B. TINJAUAN PUSTAKA}

Konsep keterbukaan informasi publik diawali terlebih dahulu melalui hakikat masyarakat terbuka. Henri Bergson berpandangan bahwa negara pada dasarnya ditutup oleh alamnya dan oleh sebab itu, mereka harus digantikan oleh moralitas yang merangkul seluruh umat manusia yang pada akhirnya mengarah pada masyarakat terbuka. Menurutnya ide demokrasi sangat sesuai karena didalamnya mengandung hak-hak asasi manusia yang sesuai. Karl Popper menjelaskan lebih dari Bergson bahwa keterbukaan mengarah pada politik demokrasi dimana pemerintah memfasilitasi keterbukaan dalam masyarakat.

Munculnya keterbukaan juga diawali oleh konsep demokrasi dalam pemerintahan. Penekanan demokrasi terletak pada kedaulatan rakyat yang bebas untuk menentukan urusan masing-masing. David Beetham (1993) berpandangan secara historis mengenai konsep demokrasi sebagai aturan masyarakat dan mengidentifikasi masyarakat sebagai mayoritas kontrol dan kesetaraan politik. Hadenius (1992) juga berpandangan bahwa setiap individu harus diperlakukan sama. Melaui demokrasi inilah akan muncul ruang publik untuk berpartisipasi dalam pemerintahan. Masyarakat bisa mempengaruhi melalui keputusan publik yang akan berdampak pada kepentingannya. 
Vaughn dan Chapman berpandangan bahwa munculnya keterbukaan diakibatkan oleh tradisi kerahasiaan oleh pemerintah. Seperti yang terjadi di Inggris pada tahun 1960an bahwa terjadi peningkatan tuntutan terhadap keterbukaan dan akses masyarakat terhadap pemerintah. Hal yang sama terjadi di Indonesia sebelum masa reformasi yang mana masyarakat hanya berikan kebijakan publik yang mengikat tanpa partisipasi masyarakat. Keterbukaan informasi juga menekankan pada pentingnya transparansi dan akuntabilitas sebagai esensi dari pemerintahan yang demokratis. Day dan Klein (1987) akuntabilitas tercapai ketika pemerintah yang demokratis bertanggung jawab terhadap rakyat. Transparansi menurut Christopher Hood menunjukkan pemerintahan yang sesuai dengan peraturan berdasarkan informasi dan prosedur yang dapat diakses oleh masyarakat. Hood menambahkan bahwa transparansi merupakan solusi pemerintahan yang lebih baik.

Oleh karena itu, dalam berbagai isu diperlukan adanya keterlibatan masyarakat baik secara langsung maupun tidak langsung. Hal tersebut bisa tercapai melalui konsep pemerintahan terbuka yang mana isu yang ada dicoba untuk disebarkan kepada masyarakat sehingga demokrasi secara nyata berperan. Vaughn dan Chapman menjelaskan bahwa pemerintah terbuka mendorong akuntabilitas, demokrasi, dan transparansi dengan melibatkan masyarakat atau orang-orang tertentu dalam pembuatan kebijakan publik untuk menjaga preferensi warga negara.

Keterbukaan informasi publik akan tercapai melalui pemerintah terbuka. Berawal dari Deklarasi Universal Hak Asasi Manusia pada pasal 19 bahwa "Everyone has the right to freedom of opinion and expression...”. Lebih lanjut bahwa kebebasan informasi merupakan teknis atau wujud nyata dari pemerintah terbuka. Dorongan deklarasi tersebut yang mendorong kebebasan informasi. Patrick Birkinshaw (2006) menekankan bahwa 'Freedom of information means access by individuals as a presumptive right to information held by public authorities'

Keterbukaan informasi oleh pemerintah juga menjadi tolak ukur dalam menilai kepercayaan publik. Penting bagi sebuah pemerintahan untuk mendapatkan kepercayaan masyarakat agar kebijakan yang telah dibuat berhasil. Sesuai dengan resolusi Plato bahwa perwakilan masyarakat (pemerintah) harus dijauhi dari segala pengaruh dan kepentingan agar kebijakan yang dibuat berdasarkan preferensi masyarakat. Kepercayaan akan timbul sesuai hukum alam. Namun Benneth dan Raab (2003) menjelaskan lebih lanjut mengenai 
kepercayaan bahwa membutuhkan waktu lama untuk membangun, mudah hancur bahkan tenggelam akibat kesalahan yang berulang.

\section{METODE PENELITIAN}

Pendekatan pada penelitian ini termasuk ke dalam jenis penelitian kualitatif. Penelitian kualitatif adalah penelitian yang bersifat deskriptif, yang mana data yang dikumpulkan dapat berupa kata-kata tertulis maupun lisan dari perilaku atau objek yang diamati serta gambar-gambar bukan angka maupun grafik (Moleolong, 1989). Dengan menggunakan pendekatan ini maka dapat digambarkan keseluruhan objek penelitian melalui analisa data kualitatif.

Data dalam suatu penelitian terdiri atas data primer dan data sekunder. Pada penelitian ini jenis data yang digunakan adalah data sekunder, yaitu data yang diperoleh tidak secara langsung dari pengamatan objek, melainkan diperoleh dari berbagai sumber literatur seperti buku, jurnal, serta dokumen resmi daerah terkait PPID DKI Jakarta.

Teknik pengumpulan data yang digunakan pada penelitian ini dilakukan dengan triangulasi berupa penelitian kepustakaan (library research) untuk memenuhi kebutuhan informasi atau bahan yang berkaitan dengan penelitian melalui tinjauan pada berbagai dokumen, buku, media massa dan situs web resmi.

\section{HASIL DAN PEMBAHASAN}

- Hasil Penelitian

\begin{tabular}{|l|l|}
\hline \multicolumn{1}{|c|}{ Statistik Layanan Informasi Publik } & Jumlah \\
\hline Daftar Informasi Publik & 2.426 \\
\hline Jumlah Unduh & 92.457 \\
\hline Jumlah Permohonan & 1.048 \\
\hline Jumlah Keberatan & 10 \\
\hline Permohonan Selesai & 10.35 \\
\hline
\end{tabular}

\section{Presentase Permohonan Selesai}

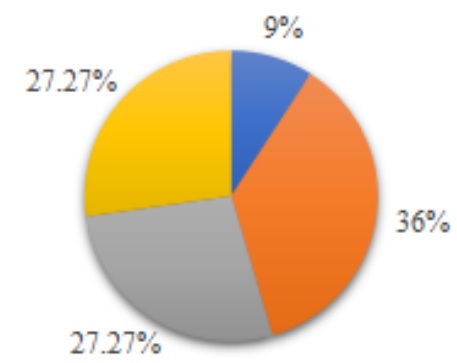

Pengecualian (1)

Tidak ditangapi (4)

- Tidak ditanggapi sebagaimana yang diminta (3)

Tidak Dipenuhi (3)

Sumber: https:/lppid.jakarta.go.id/statistik-layanan 


\section{Presentase Permohonan Selesai}

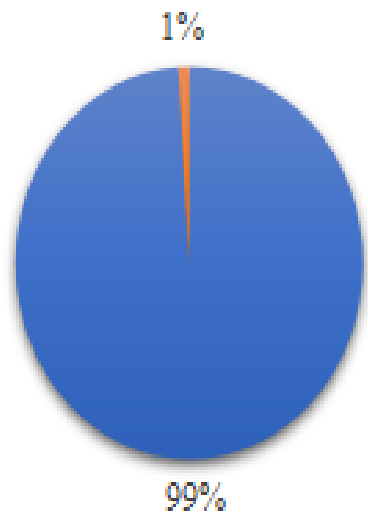

Selesai (1035) $\mathbf{D}$ Dalam Proses (13)
Presentase Permohonan Selesai

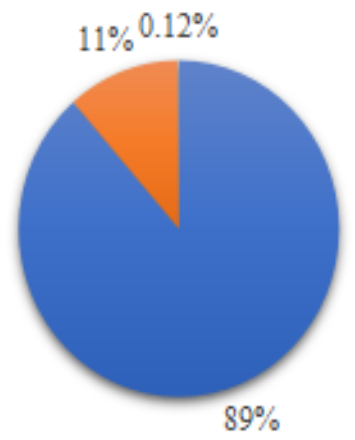

Tersedia Setiap Saat (275)

- Berkala (2148)

- Serta Merta (3)

Sumber: https://ppid.jakarta.go.id/statistik-layanan

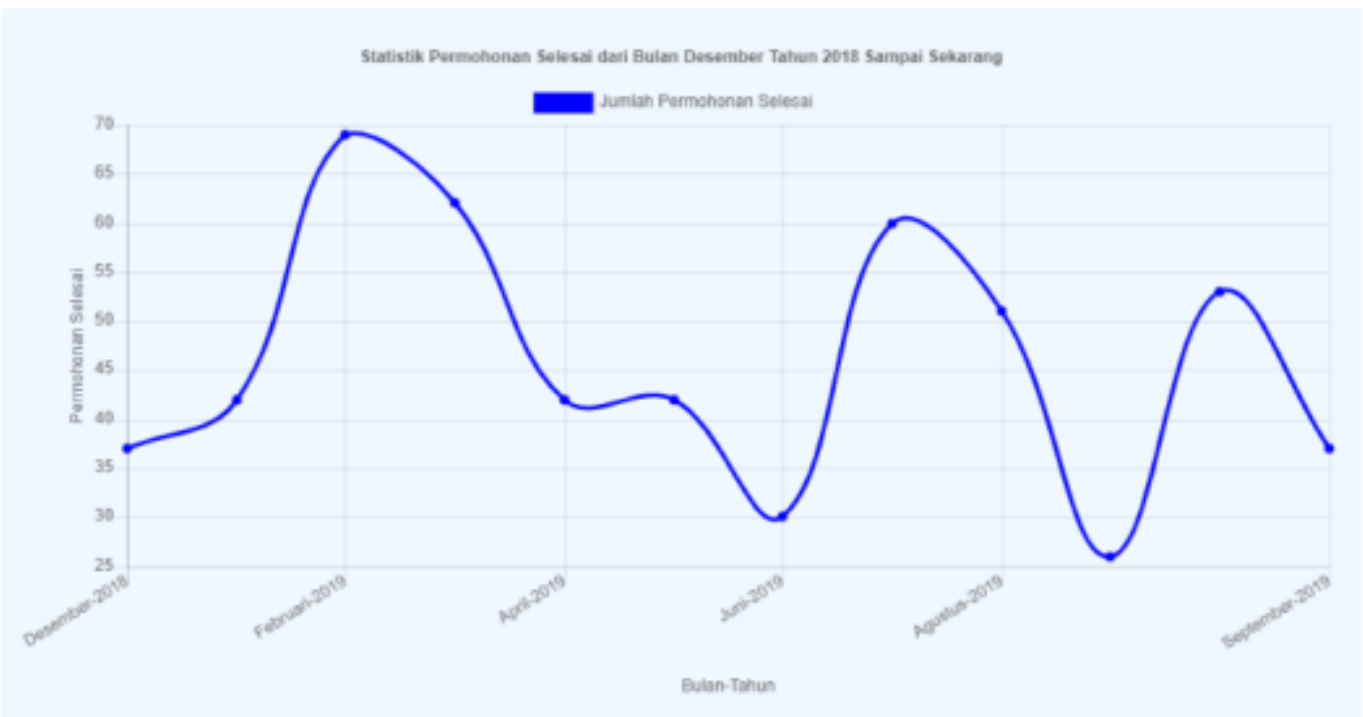

Sumber: https://ppid.jakarta.go.id/statistik-layanan

\section{- Pembahasan}

Jakarta merupakan ibukota negara Indonesia dengan populasi penduduknya mencapai 10 juta. Kondisi seperti ini tentunya berpengaruh terhadap jalannya roda pemerintahan. Sebagai negara demokrasi, tentunya partisipasi masyarakat dalam pemerintahan sangat tinggi. Oleh karena itu, pemerintah dalam hal ini memiliki kewajiban untuk memberikan ruang 
publik dimana masyarakat bisa berpartisipasi dalam proses kebijakan yang nantinya akan berpengaruh terhadap kehidupan mereka. Pemerintah Provinsi DKI Jakarta sebagai sebuah organisasi yang bertugas menjalankan pemerintahan eksekutif memiliki tanggung jawab melibatkan masyarakat sebagai implementasi dari prinsip demokrasi. Salah satu upaya konkret yang dapat dilakukan oleh Pemprov DKI Jakarta yaitu dengan memberikan pelayanan informasi terhadap masyarakat Jakarta.

\section{- Keterbukaan Informasi Pemprov DKI Jakarta}

Keterbukaan informasi merupakan suatu konsep mengenai relasi antara berbagai pihak. Lebih jelasnya bahwa keterbukaan informasi berkaitan erat dengan pemerintah dan warga negara. Pemerintah sebagai entitas yang menjalankan pemerintahan diberi kekuasaan oleh rakyat untuk mengakomodasikan berbagai kepentingan. Munculnya keterbukaan ini diawali konsep demokrasi David Beetham bahwa masyarakat sebagai mayoritas kontrol dan kesetaraan politik. Teori tersebut menunjukkan bahwa dalam konsep demokrasi, masyarakat memiliki hak partisipasi dalam pemerintahan karena memiliki kekuatan dan tidak dapat diintervensi oleh siapapun. Lebih lanjut Hadenius mengungkapkan bahwa memiliki hak yang sama dalam berpartisipasi tanpa memandang latar belakang. Konsep demokrasi akan merujuk pada kedaulatan rakyat yang mana pemerintah secara tidak sadar akan diperlakukan sebagai pelayan rakyat. Kondisi ini nantinya akan membentuk pola baru dimana pemerintah selalu diawasi oleh rakyat dalam menjalankan pemerintahan. Oleh karena itu keterbukaan informasi publik menjadi kebutuhan masyarakat. Hal tersebut terjadi pada Pemprov DKI Jakarta yang mana melalui PPID memberikan pelayanan informasi publik.

Keterbukaan informasi publik dicirikan akuntabilitas dan transparansi pemerintahan. Sejalan dengan Day dan Klein akuntabilitas pemerintahan bahwa tanggung jawab Pemprov DKI Jakarta terhadap rakyat dapat tercapai melalui penyediaan informasi mengenai kinerja yang dilakukan. Selain itu, penilaian kinerja Pemprov DKI Jakarta oleh masyarakat akan tercapai melalui informasi yang dapat diakses oleh masyarakat. seperti teori Hood bahwa transparansi akan membuat pemerintah terus melakukan perbaikan karena adanya penilaian dari kontrol mayoritas yaitu rakyat.

Keterbukaan informasi publik dicirikan akuntabilitas dan transparansi pemerintahan. Sejalan dengan Day dan Klein akuntabilitas pemerintahan bahwa tanggung jawab Pemprov 
DKI Jakarta terhadap rakyat dapat tercapai melalui penyediaan informasi mengenai kinerja yang dilakukan. Selain itu, penilaian kinerja Pemprov DKI Jakarta oleh masyarakat akan tercapai melalui informasi yang dapat diakses oleh masyarakat. seperti teori Hood bahwa transparansi akan membuat Pemerintah terus melakukan perbaikan karena adanya penilaian dari kontrol mayoritas yaitu rakyat.

Jika ditinjau secara mendalam, konsep keterbukaan informasi di Indonesia merupakan tuntutan terhadap pemerintah. teori Bergson dapat menggambarkan kondisi yang terjadi di Indonesia pada masa pemerintahan sebelumnya bahwa kerahasiaan Pemerintah membuat rakyat tidak merasa puas terhadap kinerja pemerintah. Beberapa kasus korupsi yang kian marak terjadi merupakan indikator buruknya tata kelola pemerintahan. Oleh karena itu, rakyat menuntut keterbukaan informasi publik. Sejalan dengan Popper bahwa pada akhirnya keterbukaan akan menciptakan ruang publik untuk mewadahi peran masyarakat.

Deklarasi Universal Hak Asasi Manusia juga berpengaruh terhadap lahirnya konsep keterbukaan informasi. Sebagai bagian dari PBB, Indonesia berkomitmen untuk menjalankan kesepakatan yang mengikat tersebut. Dalam deklarasi tersebut dijelaskan bahwa setiap individu berhak mendapatkan informasi. Birkinshaw juga berpandangan bahwa keterbukaan informasi ditekankan pada akses individu untuk mendapatkan informasi tanpa intervensi pihak manapun. Hal inilah yang mengawali konsep masyarakat terbuka di Indonesia. Maka sebagai respon tuntutan masyarakat. lahirlah UU nomor 14 tahun 2008 tentang KIP dan organisasi Komisi Informasi di Indonesia sebagai badan pelaksana keterbukaan informasi.

Oleh karena itu, dalam berbagai isu diperlukan adanya keterlibatan masyarakat baik secara langsung maupun tidak langsung. Hal tersebut bisa tercapai melalui konsep pemerintahan terbuka yang mana isu yang ada berusaha disebarkan kepada masyarakat sehingga demokrasi secara nyata berperan. Sesuai dengan UU nomor 14 tahun 2008 tentang Keterbukaan Informasi Publik pasal 9 bahwa Badan Publik seperti Pemprov DKI Jakarta wajib memberikan dan menyampaikan informasi publik. Pemprov DKI Jakarta sebagai badan eksekutif memiliki kewajiban untuk memberikan seluruh daftar informasi publik.

Berdasarkan Peraturan Komisi Informasi nomor 1 tahun 2010 tentang Standar Layanan Informasi Publik bahwa badan publik bisa menunjuk pejabat fungsionalis untuk membantu PPID. PPID DKI Jakarta memiliki tanggung jawab melakukan pelayanan 
informasi publik. Selain itu PPID DKI Jakarta juga berwenang mengkoordinasikan unit dibawahnya, memutuskan akses informasi publik, menolak permohonan informasi publik, dan menugaskan pejabat fungsional untuk mengelola informasi publik. Informasi publik yang dimaksud meliputi rencana kerja, keputusan, keuangan, pelaporan, dan peraturan. PPID DKI Jakarta secara langsung bertanggung jawab kepada Sekretaris Daerah.

- Implementasi UU KIP

Melalui Undang-Undang Nomor 14 Tahun 2008 tentang Keterbukaan Informasi Publik (KIP) merupakan sarana masyarakat untuk meningkatkan pengawasan terhadap penyelenggaraan berbagai kegiatan pemerintahan, serta sebagai bentuk pertanggungjawaban pemerintah dalam menjalankan amanat yang diberikan oleh masyarakat. Hal ini mendorong terbentuknya badan publik baru yaitu Pejabat Pengelola Informasi dan Dokumentasi (PPID) dengan tugas dan tanggungjawab yang diatur dalam Peraturan Pemerintah Nomor 61 Tahun 2010 (Kominfo, 2019). Selain itu, adanya UU KIP tersebut juga membentuk lembaga independen baru yaitu Komisi Informasi (KI) yang bertugas untuk menerima, memeriksa, dan memutus permohonan penyelesaian sengketa Informasi Publik melalui mediasi dan/atau ajudikasi nonlitigasi. Dalam mengamalkan UU KIP, tiap provinsi dan daerah memiliki PPID dan Komisi Informasi dengan penyesuaian masing-masing wilayah, salah satunya di Provinsi DKI Jakarta.

Provinsi DKI Jakarta merupakan salah satu provinsi yang telah menjalankan amanat dari UU KIP dengan dikeluarkannya Peraturan Gubernur Provinsi Daerah Khusus Ibukota Jakarta Nomor 175 Tahun 2016 tentang Layanan Informasi Publik sehingga terbentuk PPID Pemerintah Provinsi DKI Jakarta, serta PPID pada perangkat daerah berupa Satuan Kerja Perangkat Daerah (SKPD) dan Unit Kerja Perangkat Daerah (UKPD) yang mana seluruh tanggung jawab, tugas, fungsi dan wewenang diatur di dalamnya (PPID, 2019). Dengan adanya PPID ini di DKI Jakarta dapat mewujudkan tata kelola pemerintahan yang baik, menerapkan prinsip-prinsip akuntabilitas, transparansi dan supremasi hukum, serta mendorong sikap proaktif dan partisipatif warga Jakarta pada proses pembangunan di Jakarta.

Pemprov DKI Jakarta dalam mewujudkan pemerintahan yang terbuka untuk menyediakan informasi publik kepada masyarakat melalui situs web resmi yaitu Jakarta.go.id 
yang di dalamnya terdapat sebanyak 14 sub-indikator informasi yang dapat dengan mudah diakses oleh masyarakat, seperti laman PPID, infografis Jakarta, bank data, kanal pengaduan, informasi layanan publik Jakarta, informasi keuangan Jakarta, dll. Ditambah lagi, terdapat fitur kolom pencarian, sitemap, layanan unduh file dan ketersediaan berbagai portal untuk memudahkan masyarakat dalam mencari kebutuhan informasi secara spesifik. Hal ini terus dilakukan perkembangan dan optimalisasi oleh Dinas Komunikasi Informatika dan Statistik (Diskominfotik) terutama mengikuti pemanfaatan teknologi informasi dalam menjawab kebutuhan masyarakat Jakarta.

Dalam meningkatkan keterbukaan informasi publik dan memudahkan masyarakat menyampaikan aspirasi di Jakarta, Diskominfotik telah mengeluarkan dan mengembangkan beberapa program, sebagai berikut: 1) Jakarta Smart City, program ini dapat diakses melalui situs web smartcity.Jakarta.go.id dan merupakan pengaplikasian konsep smart city yang terintegrasi dengan sistem teknologi informasi dan komunikasi. Program ini bertujuan untuk meningkatkan transparansi, efisiensi operasional, memperbaiki pelayanan publik, serta meningkatkan kesejahteraan masyarakat melalui kerjasama dengan beberapa startup lokal untuk menghasilkan inovasi dalam pelayanan publik. Salah satu wujud perkembangan program ini adalah terintegrasinya 7.700 Circuit Closed of Television (CCTV) dengan Jakarta Smart City sehingga segala peristiwa di Jakarta dapat dipantau secara langsung oleh Pemprov DKI Jakarta (Taufan, 2019); 2) Qlue, program ini berupa aplikasi berbentuk social media yang memudahkan dan mengajak masyarakat dalam melaporkan berbagai keluhan atau aduan terhadap kondisi lingkungan dan fasilitas di Jakarta yang kemudian ditindaklanjuti oleh Pemprov DKI Jakarta; dan 3) Jakarta Aman, program ini merupakan hasil kerjasama Pemprov DKI Jakarta dengan perusahaan startup lokal yang berupa aplikasi keamanan yang digunakan masyarakat Jakarta untuk melaporkan tindak kejahatan atau urgensi pertolongan. Di dalam aplikasi ini dilengkapi berbagai fitur yang cukup lengkap berorientasi pada keamanan dan keselamatan masyarakat, seperti tombol darurat yang terhubung langsung ke call center Jakarta Siaga 112 sehingga Pemprov dapat responsif terhadap keamanan dan keselamatan warga Jakarta.

Adanya kolaborasi antara DPRD DKI Jakarta dan Pemprov DKI Jakarta juga turut meningkatkan keterbukaan informasi publik kepada masyarakat. Hal ini digiatkan dalam berbagai program informasi terhadap pengabdian masyarakat, salah satunya seperti 
pelaksanaan Sosialisasi Peraturan Daerah (Sosper) yang secara rutin dijalankan minimal satu bulan satu kali yang diadakan di tiap wilayah Jakarta oleh seluruh pimpinan dan 106 anggota DPRD sehingga masyarakat mendapatkan pengetahuan dan informasi secara menyeluruh dan mutakhir mengenai perkembangan peraturan di Jakarta (DPRD , 2019).

Dengan demikian, melalui berbagai program yang telah dicanangkan dan dilaksanakan oleh Pemerintah Provinsi DKI Jakarta dalam menyediakan berbagai kebutuhan informasi, serta menampung aspirasi dan keluhan warga Jakarta yang diwujudkan dalam berbagai media TIK, seperti situs web, aplikasi berbentuk social media, serta sosialisasi telah mampu menjawab kebutuhan masyarakat. Ditambah lagi, Diskominfotik selalu mengadakan perkembangan pada situs web dengan informasi terkini sehingga segala pendataan informasi publik terus terjaga kualitas dan kualitasnya. Oleh karena itu, Pemprov DKI Jakarta telah mengimplementasikan UU KIP dengan baik sehingga mampu meraih penghargaan Keterbukaan Informasi Publik Tahun 2019.

\section{E. KESIMPULAN}

Pejabat pengelola informasi dan dokumentasi pemerintah provinsi DKI Jakarta yang berhasil mendapatkan penghargaan Keterbukaan Informasi Publik tahun 2019 merupakan suatu pencapaian yang baik bagi pemprov DKI Jakarta, namun hal ini sejatinya tidak membuat PPID Jakarta merasa puas dan tidak mengembangkan kualitasnya. Melainkan menjadi sebuah tantangan lagi agar PPID Jakarta mampu mempertahankan pencapaian tersebut namun diiringi dengan aliran informasi yang memang dirasakan oleh masyarakat umum.

\section{- Saran}

Pemerintah provinsi lain perlu belajar dan mengevaluasi kinerja PPID nya, salah satunya dengan melihat kinerja dari PPID Pemprov DKI Jakarta. Komisi Informasi selaku badan yang bertanggung jawab akan penilaian implementasi keterbukaan informasi publik juga perlu terus memberikan pengawasan dan feedback terhadap segala jenis badan pemerintahan. Selain itu, masyarakat juga perlu memanfaatkan perannya dengan aktif dalam mengawasi segala kegiatan yang dilaksanakan oleh pemerintah provinsi DKI Jakarta. 
ARTIKEL

JURNAL PAPATUNG : Vol. 2 No. 3 Tahun 2019

ISSN : 2715-0186 


\section{DAFTAR PUSTAKA}

Febrianingsih. (2012). Keterbukaan Informasi Publik dalam Pemerintahan Terbuka Menuju Tata Pemerintahan yang Baik. Jurnal Rechtsvinding Vol. 1 No. 1, 135-156.

Krisyanto. (2016). Urgensi Keterbukaan Informasi dalam Penyelenggaraan Pelayanan Publik. Jurnal Penelitian Hukum De Jure Vol. 16 No. 2, 231-244.

Götz, N., \& Marklund, C. (2014). The Paradox of Openness : Transparency and Participation in Nordic Cultures of Consensus. Boston: BRILL.

Vaughn, R. G., \& Chapman, R. A. (2010). Freedom of Information : Local Government and Accountability. London and New York: Routledge.

Im, T. (2017). The Experience of Democracy and Bureaucracy in South Korea. United Kingdom: Emerald Publishing Limited.

Kominfo. (2019, November 30). Home: Kominfo. From Kominfo Web site: https://ppid.kominfo.go.id/about/p-p-i-d/tugas-dan-fungsi/

Komisi Informasi. (2019, November 30). Home: Komisi Informasi. From Komisi Informasi Web site: https://www.komisiinformasi.go.id/uploads/files/SLIP\%202010.pdf

KPK Organization. (2019, November 30). Home: KPK. From KPK Web site: https://www.kpk.go.id/images/pdf/uu\%20pip/UU_No_14_Tahun_2008.pdf

Pemerintah Provinsi DKI Jakarta. (2019, November 30). PPID: Jakarta. From Pemerintah Provinsi DKI Jakarta Web site: https://ppid.jakarta.go.id/statistik-layanan

Pemprov DKI Jakarta. (2019, November 30). PPID: DKI Jakarta. From Pemprov DKI Jakarta Website: https://ppid.jakarta.go.id/struktur-organisasi

PPID DKI Jakarta. (2019, November 30). PPID: Pemprov DKI Jakarta. From Pemprov DKI Jakarta Web site: https://ppid.jakarta.go.id/daftar-informasi-publik

Taufan, S. A. (2019, November 30). Home: Jawapos. From Jawapos Web site: https://www.jawapos.com/jabodetabek/01/11/2019/7-700-cctv-tersambung-jakartasmart-city/

United Nations. (2019, November 30). Documents: United Nations. From United Nations Web site: https://www.un.org/en/universal-declaration-human-rights/index.html 